\title{
Factors affecting the import of soybean in Indonesia
}

\author{
Adlaida Malik*; Saidin Nainggolan \\ Faculty of Agriculture, Universitas Jambi, Indonesia \\ To whom correspondence should be addressed.Email: adlaida.malik@gmail.com

\begin{tabular}{|l|l|l|l|l}
\hline DOI: & Received: & Revised: & Accepted: & Published:
\end{tabular}

\begin{tabular}{l|l|l|l|l}
$10.22437 /$ ppd.v8i5.11015 & 13.11 .2020 & 20.12 .2020 & 30.12 .2020 & 31.12 .2020 \\
\hline
\end{tabular}

\begin{abstract}
As an agricultural country, Indonesia still imports soybeans to meet domestic soybean needs. The gap between national soybean production and consumption causes the government to import. Based on this, this study aims to analyze the factors that influence soybean imports in Indonesia. The data used are time series data for the period 20032018. Data is sourced from the Food and Agriculture Organization (FAO), United Nations International Trade Statistics Database (UN COMTRADE), the Central Bureau of Statistics of the Republic of Indonesia, World Bank, Bank Indonesia, and the Ministry of Trade of the Republic of Indonesia. The analysis method uses SEM-Partial Least Square (PLS). The results showed that the macroeconomic conditions directly affect soybean production and consumption. On the other hand, consumption has a direct effect, but production has no direct effect on soybean imports. Macroeconomic conditions do not have a direct effect on soybean imports. Nevertheless, the total effect (combined direct and indirect effects) is significant from macroeconomic conditions on soybean imports.
\end{abstract}

Keywords: Consumption, Import, Macroeconomics, Production, Soybean

JEL Classsification: E21, E23, F16, Q17, Q18

\section{INTRODUCTION}

Global trade is an essential aspect of the economy in every country. Global trade aims to improve people's welfare in a country (Destasari et al., 2015). Community welfare is reflected in their food condition: the more food a country can supply, the more prosperous the people in that country (Junaidi et al. 2020a; Junaidi et al. 2020b).

Soybean is one of the main food commodities after rice and corn. Soybeans are the main source of vegetable protein for the community. Food ingredients from other plants have not been found, such as soybeans, which are very rich in protein (Andayanie, 2016). In Indonesia, almost 90\% of soybeans are used for food (Atman, 2014). According to Silitonga \& Djanuwardi in Ginting et al. (2009), tempeh and tofu dominate soybeans' use for food, namely $50 \%$ and $40 \%$, respectively. The rest is used for processing soy milk, soy sauce, flour, and other preparations.

Domestic demand for soybeans increases every year due to increased consumption (BPS, 2019). However, the increase in soybean consumption was not matched by production. Based on data from 2018, the soybean harvested area in Indonesia reached 582 thousand ha with a production of 811 thousand tons (Food and Agriculture Organization, 2019). Domestic soybean production is only able to meet $47.7 \%$ of domestic needs. According to Andayanie (2016), the narrower planting area and less optimal land use have led to a decrease in Indonesia's soybean production. 
The government has implemented various types of policies to increase soybean production. However, the amount of domestic soybean production is still not able to meet domestic soybean consumption needs. The imbalance between soybean production and consumption each year causes Indonesia to import soybeans. Imported soybeans will hurt the welfare of local farmers. The public will choose imported soybeans over local soybeans because imported soybeans' price is lower than local soybeans.

Apart from production and consumption factors, the volume of soybean imports is also influenced by macroeconomic conditions. Based on previous studies, macroeconomic factors that affect imports are inflation, GDP, interest rates, and the rupiah exchange rate, which are included in macroeconomic variables (Bank Indonesia in Kurniasarin et al., 2019; Anggasari, 2008; Limaei et al. 2011; Febyola, 2019 Fatukasi \& Awomuse, 2011). Inflation causes imported goods to be relatively cheap so that the country will import more. An increase in the GDP of a country means an increase in people's ability to import products from other countries. High-interest rates will increase costs incurred by producers, resulting in a decrease in domestic production. Furthermore, if the value of a country's currency against another country's currencies increases (appreciates), the price of that country's product for foreign parties will be higher. In contrast, the price of imports for domestic residents is lower.

An increase in imported soybeans' volume needs to be analyzed because it can lead to dependence on imported soybeans. The phenomenon of soybean consumption, which tends to increase with low production and the volume of soybean imports that tends to increase following the increasing trend in consumption, illustrates instability in soybeans in Indonesia, and the government is still dependent on imports compared to natural potential in Indonesia. Therefore, it is important to know what factors influence soybean imports in Indonesia.

\section{METHODS}

The data used are time series data for the period 2003-2018. Data is sourced from the Food and Agriculture Organization (FAO), United Nations International Trade Statistics Database (UN COMTRADE), the Central Bureau of Statistics of the Republic of Indonesia, World Bank, Bank Indonesia, and the Ministry of Trade of the Republic of Indonesia.

To analyze the factors that influence soybean imports using the SEM-PLS model with the following model framework:

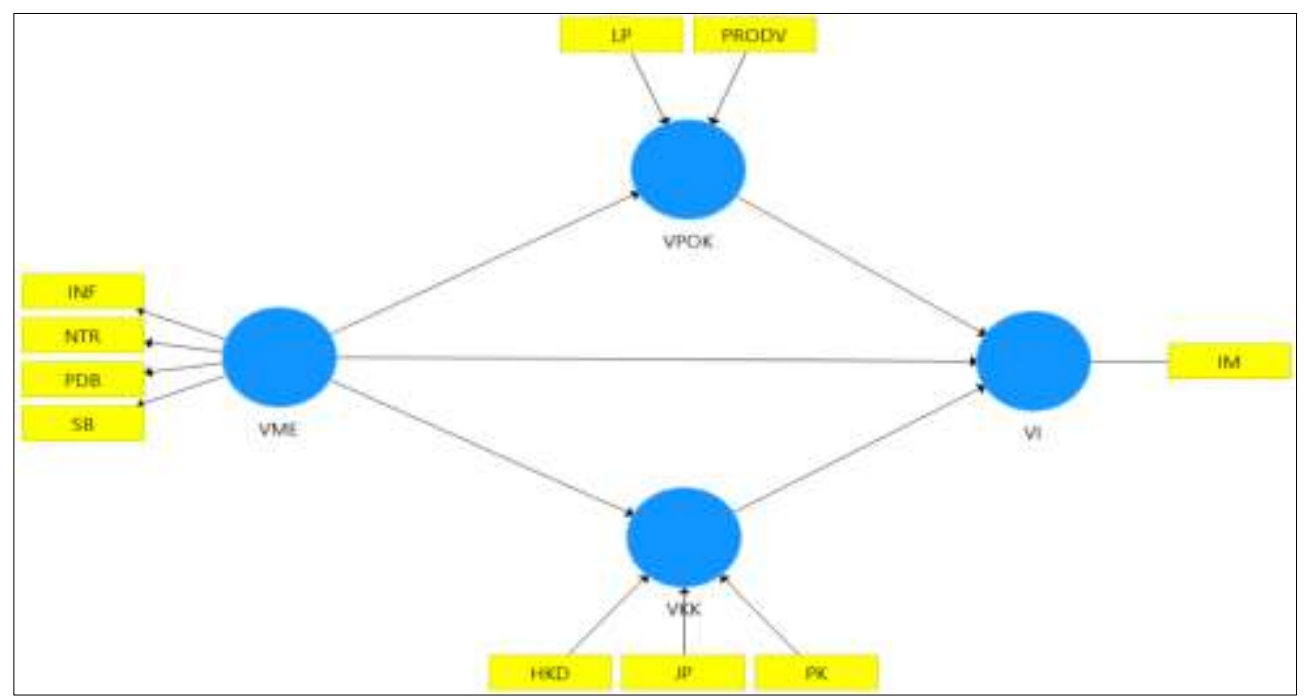

Figure 1. Model of factors affecting soybean imports in Indonesia. 
Notes:

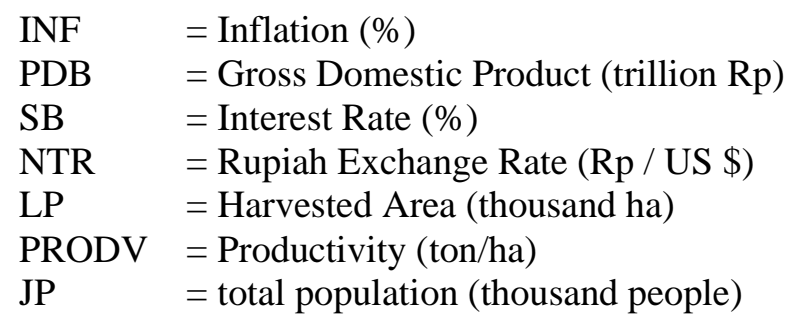

$$
\begin{array}{ll}
\text { PK } & =\text { Soybean Supply (thousand tons) } \\
\text { HKD } & =\text { Domestic Soybean Price (Rp } / \text { ton) } \\
\text { IM } & =\text { Volume of imports (thousand tons) } \\
\text { VME } & =\text { Macroeconomic Variable } \\
\text { VPO } & =\text { Soybean Production Variable } \\
\text { VKK } & =\text { Soybean Consumption Variable } \\
\text { VI } & =\text { Soybean Import Variable }
\end{array}
$$

The SEM-PLS model framework is analyzed through the following stages:

\section{Outer model evaluation}

Before conducting further analysis, first, an evaluation of the initial model is related to the indicators' validity and reliability in the latent variables (constructs). As shown in Figure 1, the model tested has two types of constructs, namely constructs with reflective indicators and constructs with formative indicators.

Evaluation of the outer model for reflective indicators using a convergent approach and discriminant validity and composite reliability. Convergent validity is assessed based on the correlation between the item score/component score with the construct score. The individual reflexive size is high if the correlation (loading value) is more than 0.70 and sufficient if it is between 0.50 to 0.60 . Discriminant validity indicators are assessed based on the average variance extracted (AVE) value. If the AVE value is greater than 0.50 , then the construct is declared valid. Composite reliability was evaluated using Cronbach's Alpha. The indicator block is declared reliable if the Cronbach's Alpha value is above 0.60 (Gozali and Hengky, 2015).

Furthermore, evaluating the outer model for formative indicators is based on its substantive content, namely by comparing the relative weight values and testing the significance of weight measurements.

\section{Inner model evaluation}

The inner model is evaluated by looking at the percentage of variance described by looking at the $\mathrm{R}^{2}$ value for the latent dependent construct. The goodness-fit of the model is measured using the $\mathrm{R}^{2}$ value. According to Chin (1998) in Ghozali \& Hengky, 2015, the R2 criteria consist of three classifications: R2 values $0.67,0.33$, and 0.19 as substantial, moderate, and weak.

Another test in structural measurement is $\mathrm{Q}^{2}$ predictive relevance, which serves to validate the model. Calculation of $\mathrm{Q}^{2}$ is done with the formula $\mathrm{Q} 2=1-\left(1-\mathrm{R} 1^{2}\right)\left(1-\mathrm{R} 2^{2}\right)$ ..... (1-Rp $\mathrm{R}^{2}$, where $\mathrm{R} 1^{2}, \mathrm{R} 2^{2} \ldots \mathrm{Rp}^{2}$ are $\mathrm{R}^{2}$ endogenous variables in the equation model. The value of $\mathrm{Q}^{2}$ ranges from $0<2<1$, the closer to 1 means that the model is getting better (Jaya \& Sumertajaya, 2008).

Furthermore, the hypothesis test for latent variables in the structural model is tested through the $\mathrm{t}$ statistic test.

\section{RESULTS AND DISCUSSION}

\section{Description of research variables}

During 2013 - 2018, the average import of soybeans in Indonesia was 1,775 thousand tons per year. During this period, soybean imports grew by an average of 7.78 percent per year, from 1,193 thousand tons in 2003 to 2,586 thousand tons in 2018 .

The conditions and development of soybean imports and the variables in the study are given in Table 1. 
Table 1. Description of research variables

\begin{tabular}{|c|c|c|c|c|}
\hline \multirow{2}{*}{ Variable } & \multicolumn{2}{|c|}{ Year } & \multirow[b]{2}{*}{ Average } & \multirow{2}{*}{$\begin{array}{l}\text { Growth per } \\
\text { year }(\%)\end{array}$} \\
\hline & 2003 & 2018 & & \\
\hline Soybean import (thousand tons) & 1193.00 & 2586.00 & 1775.19 & 7.78 \\
\hline Inflation (\%) & 6.79 & 3.03 & 6.45 & -3.69 \\
\hline GDP (Trillion Rupiah) & 2144.00 & 14837.00 & 7645.56 & 39.47 \\
\hline Interest rate $(\%)$ & 9.94 & 5.60 & 7.26 & -2.91 \\
\hline Rupiah exchanger rate per 1 US\$ & 8577.00 & 14238.00 & 10593.69 & 4.40 \\
\hline Soybean harvested area (thousand ha) & 527.00 & 680.00 & 582.25 & 1.94 \\
\hline Productivity of soybean (ton/ha) & 1.28 & 1.44 & 1.39 & 0.83 \\
\hline Population (thousand inhabitants) & 220309 & 267663 & 243765 & 1.43 \\
\hline Soybean stock (thousand ton) & 201 & 436 & 273 & 7.79 \\
\hline Domestic soybean price (Rp/ton) & 3766000 & 10530000 & 8333875 & 11.97 \\
\hline
\end{tabular}

Based on the macroeconomic aspect, the average inflation rate during the 2003 2018 period was 6.45 percent. In the GDP at current prices, there was a growth of 39.47 percent per year from Rp. 2,144 trillion in 2003 to Rp. 14837 trillion in 2018. Furthermore, the average Bank Indonesia interest rate in that period was 7.26 percent, and the average exchange rate rupiah, amounting to IDR 10,539.69 per 1 US \$.

In production indicators, the average soybean harvested area during 20013 - 2018 was 582 thousand hectares with a growth of 1.94 percent per year. Meanwhile, the average land productivity was 1.39 tonnes per ha, with a growth of 0.83 percent per year.

Furthermore, in consumption indicators, the average population growth rate in the 2003 - 2018 period was 1.43 percent per year. The average supply of soybeans is 273 thousand tons, with an average growth of 7.79 percent per year. The average domestic soybean price is IDR 8,333,875 per ton, with an average growth of 11.97 percent per year.

\section{Factors affecting the import of soybean in Indonesia}

\section{Outer model evaluation}

The initial model evaluation used convergent testing, discriminant validity, and composite reliability for the VME indicator block and the significant weight for the VPOK and VKK indicator blocks. Based on the initial model testing, it was found that there is one indicator in the VPOK variable, namely LP, which is not feasible and must be removed from the model. Permadi's (2015) research shows that the harvested area has not explained the soybean production variables. The modification model (after issuing invalid and reliable indicators) is given in Figure 2.

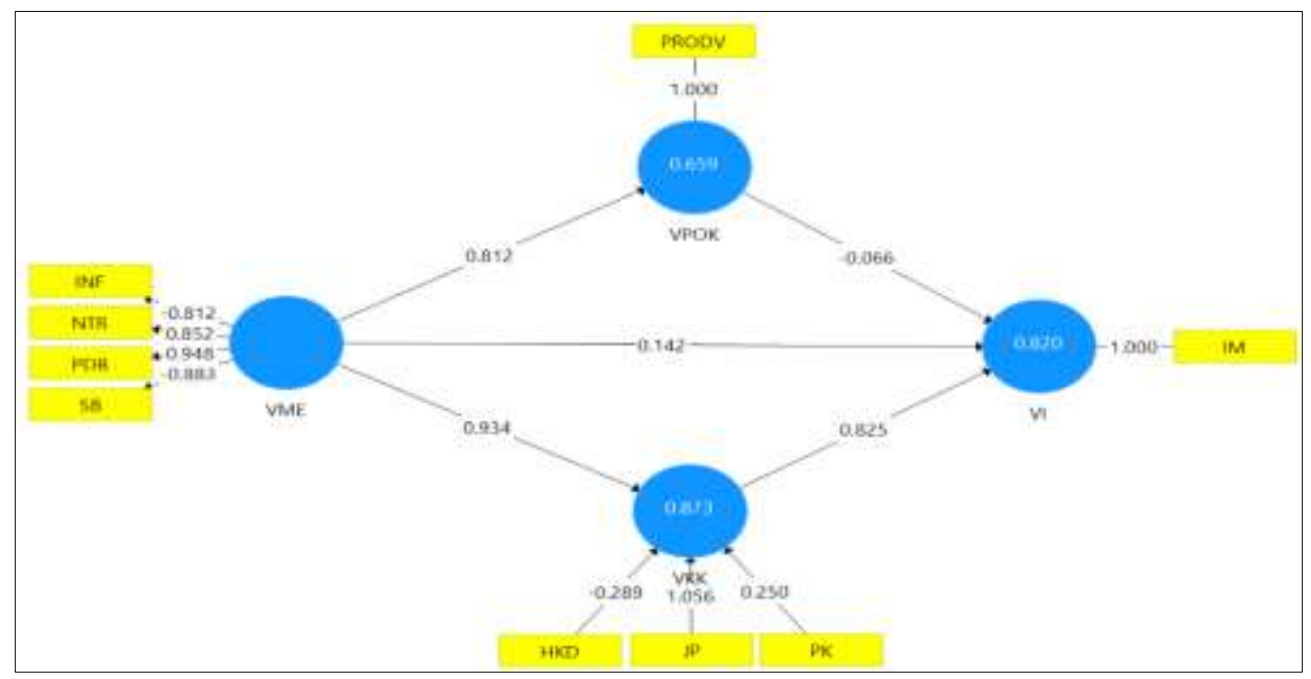

Figure 1. Modified model of factors affecting soybean imports in Indonesia 
Based on Figure 2, the correlation (loading factor) of all the VME construct indicators (as a latent variable with a reflective indicator) is already above 0.5 . Furthermore, based on testing, the VME indicator block's AVE value is 0.766, and Cronbach's Alpha is 0.658 . In other words, the model has good reliability.

Evaluate the VKK block's outer model as a formative indicator block (note: no testing is done for the VPOK block because there is only one indicator), using a significance weight. Based on Table 2, all VKK block indicators are statistically significant, so they are valid for the model.

Table 2. Testing the significance of weight measurements (VKK block's outer model)

\begin{tabular}{lrrrrr}
\hline & $\begin{array}{r}\text { Original } \\
\text { Sample }(\mathrm{O})\end{array}$ & $\begin{array}{r}\text { Sample Mean } \\
(\mathrm{M})\end{array}$ & $\begin{array}{r}\text { Standard } \\
\text { Deviation } \\
\text { (STDEV) }\end{array}$ & $\begin{array}{r}\text { T Statistics } \\
(\mid \mathrm{O} / \text { STDEV|) }\end{array}$ & P Values \\
\hline HKD -> VKK & 0.848 & 0.835 & 0.081 & 10.431 & 0.000 \\
JP -> VKK & 0.978 & 0.958 & 0.042 & 23.190 & 0.000 \\
PK -> VKK & 0.851 & 0.838 & 0.135 & 6.287 & 0.000 \\
\hline
\end{tabular}

\section{Goodness-of-fit model}

Table 3 provides the $\mathrm{R}^{2}$ value for each of the latent dependent constructs in the model. Construct VI has an $\mathrm{R}^{2}$ value of 0.8196 , VKK has an $\mathrm{R}^{2}$ value of 0.8727 , and VPOK has an $\mathrm{R}^{2}$ value of 0.6586 . In other words, models with constructs VI and VKK are categorized as strong, and models with constructs VPOK are categorized as moderate.

Table 3. The $\mathrm{R}^{2}$ value of the latent dependent construct

\begin{tabular}{ccc}
\hline & R-Squared & Adjusted R-Squared \\
\hline VI & 0.8196 & 0.7745 \\
VKK & 0.8727 & 0.8636 \\
VPOK & 0.6586 & 0.6342 \\
\hline $\mathbf{Q}^{\mathbf{2}}$ & 0.9849 & \\
\hline
\end{tabular}

Furthermore, based on the value of Q2, the magnitude of the research data's diversity that can be explained by the structural model is $98.49 \%$. It means that the structural model has a very high predictive relevance.

\section{Hypothesis testing and interpretation of the relationship between variables}

The influence between variables can be seen from the coefficient value and significance of the $t$ statistic. The effect is significant if the probability of $t$ statistic is smaller than $\alpha=1 \%, 5 \%$, or $10 \%$.

Table 4 shows that Macroeconomic conditions (VME) directly positively and significantly affect Soybean Production (VPOK). It can be interpreted that directly every change in macroeconomic conditions with indicators of inflation, GDP, interest rates, and the rupiah exchange rate will increase soybean production. Macroeconomic Variable (VME) also positively and significantly affects Soybean Consumption (VKK). It can be interpreted that immediately every change in indicators of macroeconomic conditions will increase soybean consumption. However, macroeconomic conditions do not have a significant direct effect on soybean imports.

Soybean Production (VPOK) does not have a significant direct effect on imports. This study's results are in line with Ripaldi's (2017) research and Destasari (2015), which show that production does not significantly affect soybean imports in Indonesia. Even though soybean production has increased, but soybean reserves are not sufficient for the needs, the government continues to import soybeans. 
Table 4. Testing the model hypothesis

\begin{tabular}{lrrrrr}
\hline & $\begin{array}{r}\text { Original } \\
\text { Sample (O) }\end{array}$ & $\begin{array}{r}\text { Sample } \\
\text { Mean (M) }\end{array}$ & $\begin{array}{r}\text { Standard } \\
\text { Deviation } \\
(\text { STDEV })\end{array}$ & $\begin{array}{r}\text { T Statistics } \\
(\mid \text { OSTDEV })\end{array}$ & P Values \\
\hline Direct effect & & & & & \\
\hline VME -> VPOK & 0.812 & 0.714 & 0.413 & 1.966 & 0.050 \\
VME -> VKK & 0.934 & 0.817 & 0.453 & 2.062 & 0.040 \\
VME -> VI & 0.142 & -0.007 & 0.408 & 0.349 & 0.727 \\
VPOK -> VI & -0.066 & -0.088 & 0.228 & 0.291 & 0.771 \\
VKK -> VI & 0.825 & 0.998 & 0.393 & 2.100 & 0.036 \\
\hline Indirect effect & & & & & \\
\hline VME -> VPOK -> VI & -0.054 & -0.054 & 0.204 & 0.264 & 0.792 \\
VME -> VKK -> VI & 0.771 & 0.810 & 0.575 & 1.340 & 0.181 \\
\hline Total effect & & & & & \\
\hline VME -> VI & 0.859 & 0.749 & 0.422 & 2.037 & 0.042 \\
\hline
\end{tabular}

Consumption of Soybean (VKK) directly has a positive and significant effect on imports. It can be interpreted that any increase in soybean consumption will increase imports. It is in line with the research of Nainggolan et al. (2016), which shows that soybean consumption has a significant effect on soybean imports in Indonesia and Sari's research (2015) has a significant and positive effect between soybean imports and soybean consumption due to the very high demand for soybeans in Indonesia.

These results are consistent with Putri's (2015) research, which states that soybean imports are significantly influenced by soy consumption. Higher soybean consumption has the potential to increase soybean imports. Initially, soybeans were only used for making tempeh, tofu, and soy sauce. However, along with technological developments, the medical and cosmetic world also uses soy as the main ingredient. It has led to an increase in soy consumption.

Statistically, macroeconomic conditions do not have an indirect effect on soybean imports either through production or consumption. However, in total (the sum of direct and indirect effects), macroeconomic conditions significantly affect soybean imports. It is in line with the research of Anggasari (2008) and Limaei et al. (2011), which shows the influence of macroeconomic conditions on imports.

\section{CONCLUSIONS AND RECOMMENDATIONS}

\section{Conclusions}

Macroeconomic conditions directly affect soybean production and consumption. On the other hand, consumption has a direct effect, but production has no direct effect on soybean imports.

Macroeconomic conditions do not have a direct effect on soybean imports. Nevertheless, the total effect (combined direct and indirect effects) is significant from macroeconomic conditions on soybean imports.

\section{Recommendations}

The government must strive to set the price of soybeans according to the community's ability. The government must control the domestic soybean price to remain stable and does not experience a sharp increase. It is intended that the domestic soybean price is not higher than the price of imported soybeans to reduce losses on the part of farmers and improve welfare. 


\section{REFERENCES}

Andayanie, W.R. (2016). Pengembangan produksi kedelai sebagai upaya kemandirian pangan di Indonesia. Jakarta: Mitra Wacana Media

Anggasari, P. (2008). Analisis faktor-faktor yang mempengaruhi volume impor kedelai Indonesia. [Thesis]. Faculty of Economics and Management, Institut Pertanian Bogor. Bogor.

Atman. (2014). Produksi kedelai strategi meningkatkan produksi kedelai melalui PTT. Yogyakarta: Graha Ilmu

BI. (2019). Inflasi. Jakarta: Bank Indonesia.

BI. (2019). Suku bunga di Indonesia. Jakarta: Bank Indonesia.

BPS. (2019). Konsumsi kedelai. Jakarta: Badan Pusat Stasitik.

Destasari. A.N., Suharyono \& Edi Y. (2015). Pengaruh produksi kedelai dalam dan harga kedelai dunia terhadap volume impor kedelai di Indonesia (Studi terhadap volume impor kedelai tahun 1996-2013). Jurnal Administrasi Bisnis (JAB). 1(1), 1 - 8.

FAO. (2019). Exchange Rate. Food and Agriculture Organization.

FAO. (2019). Gross Domestic Product Indonesia. Food and Agriculture Organization.

FAO. (2019). Indonesian Soybean Harvest Area. Food and Agriculture Organization.

FAO. (2019). Indonesian Soybeans Production. Food and Agriculture Organization.

FAO. (2019). Indonesian Soybeans Stock. Food and Agriculture Organization.

Fatukasi, B., \& Awomuse, B.O. (2011)., determinants of import in Nigeria: Application of error correction model, Centrepoint Journal, Humanities edition, 14(1), 52-72

Febyola. (2019). Analisis faktor-faktor yang mempengaruhi volume impor beras di Indonesia dengan pendekatan Partial Least Square (PLS). [Thesis]. Faculty of Agriculture, Universitas Jambi. Jambi.

Ghozali, I. \& Hengky L. (2015). Partial least squares konsep teknik dan aplikasi menggunakan program smart pls 3.0 untuk penelitian empiris. Semarang: Badan Penerbit Universitas Diponegoro.

Ginting, E., Antarlina, S.A. \& Widowati, S. (2009). Varietas unggul kedelai untuk bahan pangan baku industri pangan. Jurnal Penelitian dan Pengembangan Pertanian, 28(3), $79-87$

Jaya I Gede NM, \& IM Sumertajaya. (2008). Permodelan persamaan struktural dengan partial least square. Bogor, Semnas Matematika dan Pendidikan Matematika.

Junaidi, J., Yulmardi, Y. \& Hardiani, H. (2020 $)$. Food crops-based and horticulture based villages potential as growth center villages in Jambi Province, Indonesia. International Journal of Advanced Science and Technology, 29(3), 6118 - 6133

Junaidi, J., Amir, A., \& Amril, A. $\left(2020^{\mathrm{b}}\right)$. Analysis of the Socio-EconomicDemographic Characteristics of the Family, Social Capital and Economic Coping Strategy in Increasing Food Security for Urban Poor Households in Jambi Province, Indonesia. Dirasat, Human and Social Sciences, 47(2), 408 - 424

KEMENDAG. (2018). Analisis Outlook Pangan 2015-2019. Jakarta: Kementerian Perdagangan.

Kurniasari, F. \& Lisa, M. (2019). Pengaruh nilai tukar, suku bunga dan produk domestik bruto terhadap volume ekspor impor di Indonesia. Journal of Business \& Applied Management. 12(1), 1-11.

Limaei, S.M., Heybatian, R., Vaezin, S.M.H \& Torkman, J. (2011). Wood import and export and its relation to major macroeconomics variables in Iran. Forest Policy and Economics, 13(4), 303 - 307 
Mahardika, K.A.W. \& Yuliarmi, N.N. (2018). Pengaruh jumlah penduduk, produksi, pdb dan kurs dollar amerika serikat terhadap impor cabai Indonesia. E-Jurnal EP Unud, 7(3), 502-530.

Nainggolan, K.U., Agung, I.D.G.A \& Tenaya, M.N. (2016). Pengaruh produksi, konsumsi, dan harga kedelai nasional terhadap impor kedelai di Indonesia periode 1980-2013. E-Jurnal Agribisnis dan Agrowisata. 5(4), 742 - 751.

Permadi, G.S. (2015). Analisis permintaan impor kedelai Indonesia. Jurnal EkoRegional, 10(1), 23 - 31

Putri, A.N. (2015). Faktor-faktor yang mempengaruhi impor kedelai di Indonesia tahun 1981-2011. Jurnal Ekonomi Pembangunan, 4(2), 98 - 105

Ripaldi, M. (2017). Analisis faktor-faktor yang mempengaruhi volume impor kedelai di Indonesia. [Thesis]. Faculty of Agriculture, Universitas Jambi. Jambi.

Sari, P.M. (2015). Analisis faktor-faktor yang mempengaruhi konsumsi kedelai di Indonesia. Journal of Economic and Economic Education. 4(1), 30-41.

Tan, S. (2014). Perdagangan internasional teori dan beberapa aplikasinya. Jambi: CV Bukit Mas.

UN COMTRADE. (2019). Statistics Database. United Nations Commodity Trade.

World Bank. (2019). Perkembangan harga kedelai dunia tahun 2003-2017. World Bank.

World Bank. (2019). Population total in Indonesian. World Bank.

(C) 2020 by the authors. Licensee JPPD, Indonesia. This article is an open-access article distributed under the terms and conditions of the Creative Commons Attribution (CC BY) license (http://creativecommons.org/licenses/by/4.0/). 